\title{
SUPPORTING BUILDING ADMINISTRATOR'S DECISIONS IN DETERMINING MAINTENANCE COSTS OF RESIDENTIAL BUILDINGS
}

\author{
Robert BUCOŃ, Michał TOMCZAK \\ Department of Construction Project Engineering, Faculty of Civil Engineering and Architecture, Lublin \\ University of Technology, Nadbystrzycka 40 str., 20-618, Lublin, Poland
}

Received 07 December 2015; accepted 22 March 2016

\begin{abstract}
Maintenance of multi-family buildings is a difficult and complex task, which requires a proper (multi-criteria) assessment of a building's condition as well as determining and planning maintenance costs. It requires from a building administrator to be well experienced and have skills in making decisions, which include a proper investment of limited funds allocated for maintenance. This task is usually preceded by the analysis of cost-effectiveness and validity to perform certain repairs. Taking into account the above the authors proposed a model supporting an administrator in making decisions while determining a scope of building renovation. The system algorithm proposed comprises a few stages including: building condition and its proposed repair evaluation and the choice of renovation variant. It is based on tools such as multicriteria methods to support decisions and linear programming. Calculations conducted using the suggested model allow an administrator to obtain key information for appropriate maintenance of a building, i.e. to determine a renovation variant and its cost as well as a monthly renovation contribution (at assumed number of years) to achieve assumed condition of a building.
\end{abstract}

Keywords: building maintenance, criteria of building condition, building evaluation, renovation, multi-criteria evaluation.

\section{Introduction}

The way of residential buildings maintenance in Poland does not provide the appropriate level of their maintenance. This is due to legal provisions which impose on the administrator the obligation to maintain the building in an unimpaired condition, but they do not determine either the maintenance standard or the way of its evaluation (The Real Estate Management 1997). The main problem of improper buildings' maintenance results from the scope of evaluation they are subjected within obligatory control. Buildings are evaluated in terms of a technical condition of structure, finishing, installation and visual environment of a building. This evaluation, however, does not include basic requirements such as structure, utility and fire safety, thermal, acoustic and environmental protection etc. Despite the difficulties that the evaluation of the mentioned criteria poses, many complex methods of evaluating buildings have been developed (Ho et al. 2012; Yau 2008; Kasprowicz 2005). Many researchers recognized the need to take into account in the building's evaluation additional criteria of economic, social, cultural, ecological and aesthetic aspects (Juan et al. 2009; Mickaityte et al. 2008; Kaklauskas et al. 2005; Zavadskas et al. 1997).

Incomplete information about building's condition does not provide necessary data to make decisions ensuring an appropriate level of building's maintenance (Christen et al. 2014; Raslanas et al. 2011; Zavadskas et al. 2004). Appreciable effects of such measures will be

Corresponding author:

R. Bucoń E-mail: r.bucon@pollub.pl 
visible after some time negligence, which will adversely affect the utility and market value of buildings (Bucoń, Sobotka 2015). The basic task for improving the quality of buildings' maintenance is complex evaluation of a building's condition. For this purpose various methods are used including multi-criteria support decision making support known in the literature as MADM (Multiple Criteria Decision Making) (Perng et al. 2007; Kaklauskas et al. 2005; Zavadskas et al. 1997) and others, ie. LEED, BREAM, CASBEE, etc. (Alchimoviené, Raslanas; Reed et al. 2011; Roderick et al. 2009). Another important factor influencing the quality of maintenance is the way of building's maintenance, which involves such criteria evaluation as the rights and responsibilities of administrator, record keeping, planning current activities (e.g. cleaning), emergency preparedness, financial plans (planned and unplanned expenditures) (Ho et al. 2012, 2008; Yau et al. 2008).

A key objective of a maintenance process of residential buildings is both providing funds for expenditures related to repairs and planning their spending (Lin, Pan 2014; Christen et al. 2014; Raslanas et al. 2011; Rosenfiels, Shohet 1999). The main source of the budget which covers repairs in a building are contributions for so - called renovation fund. The problems related to the determination of the amount of the budget providing the appropriate level of maintenance of a building, as well as the optimal allocation of financial resources for renovation, are the subject of many scientific studies. In the literature there are many methods proposed to solve these problems. They are based, among others, on expert systems and artificial intelligence (Juan et al. 2009; Perng et al. 2007; Bucoń, Sobotka 2015). Many other comprehensive tools to determine the renovation cost, renovation scenarios evaluation are suggested to ensure a proper level of buildings' maintenance. TOBUS (European diagnostics and decision-making Tool for Office Building Upgrading Solutions) developed by Caccavelli and Gugerli (2002) for evaluating office buildings, XENIOS by Dascalaki and Balaras (2004) for hotels and EPIQR (Energy Performance and Indoor Quality Retrofit) developed by Kolokotsa et al. (2009) for residential buildings are the examples.

Recognition and analysis of methods and models proposed in the literature concerning the management of buildings' maintenance formed the basis the authors' study to develop an original method, whose task is to identify the most favourable renovation variant taking into account the limitations of funds availability. The solution suggested by the authors include the extensive evaluation of building's condition, the evaluation of proposed repairs and their selection based on two assumptions. The first assumes that for specific amount of budget, a repair variant with the highest increase of a building's condition is sought. The second one involves achieving the cheapest solutions to get assumed value of building's condition or individual criteria. Additionally, the model allows to determine the amount of repair contribution, to achieve a particular condition of a building assuming different accounting periods. It is possible due to the choice of appropriate amount of renovation contribution tailored to financial resources of residents.

\section{The description of a suggested method}

The suggested model consists of five crucial stages demonstrated in Figure 1. The first one involves extended evaluation of building's condition according to adopted criteria. The next stage is assessing proposed repairs that can be made using a variety of technologies and materials. The third one is determining the most

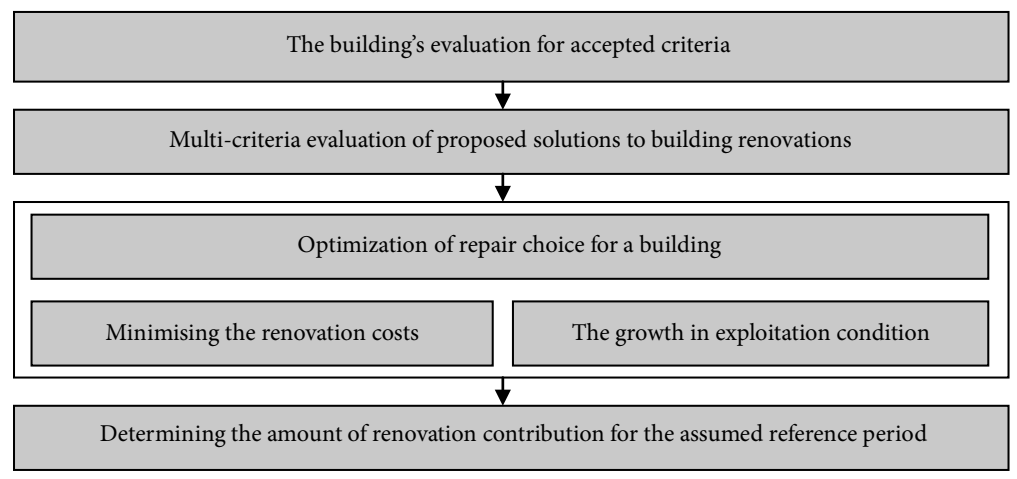

Fig.1. Stages of the proposed method 
favorable repair variant for the adopted optimization criteria. The last stage is to determining the amount of monthly contribution for the so-called renovation fund, for the assumed reference period.

The detailed description of particular stages of a developed approach together with the description of applied computational methods are set out in sections 1.1-1.3.

\subsection{The building's evaluation for assumed criteria}

For the evaluation of criteria $o_{k}$, the 'weighted average' method was applied (1), in which particular $i$-th elements, having the impact on $k$-th criterion, are assessed with the use of a five-step scale of linguistic evaluations, i.e.: very good VG $(5 \mathrm{pt})$, good $\mathrm{G}(4 \mathrm{pt})$, average A (3 pt), bad B (2 pt), very bad VB (1 pt), not evaluated $\mathrm{N}$. The intermediate evaluations can also be applied, i.e.: VG/G (4.5 pt), G/A (3.5 pt), A/B (2.5 pt), $\mathrm{B} / \mathrm{VB}(1.5 \mathrm{pt})$.

$$
O_{k}=\sum_{i=1}^{n} w_{i k} \cdot O_{i k}, \quad \forall k=1,2, \ldots, q,
$$

where: $w_{i k}, o_{i k}$ - respectively weight and evaluation of $i$-th element for $k$-th criterion, $n$ - the number of assessed elements for every criterion.

\subsection{Multi-criteria evaluation of building renovations}

The evaluation of building elements with the use of linguistic expressions provides the basis for determining necessary renovation works, i.e. repairs. The suggested repairs can affect the improvement of assumed criteria $p_{i j}$ to a varying degree. They can be carried out in many different ways, so-called variants, each of which shows different solution in terms of applied materials, technology and costs of performance. The growth estimation of $j$-th variant of $i$-th renovation, in reference to the each of adopted $k$-th criteria, is conducted according to the equation (2):

$$
\begin{aligned}
& p_{i j k}=\left(O_{i}-O_{i k}\right) \cdot \frac{O_{i j}}{O_{j}} \cdot w_{i k}, \quad \forall i=1,2, \ldots, n, \\
& \forall j=1,2, \ldots, m, \quad \forall k=1,2, \ldots, q,
\end{aligned}
$$

where: $o_{i j k}$ - the impact of $j$-th repair on the improvement of the condition of $i$-th element, adopted to the assessment of $k$-th criterion, which is assessed with the use of the following linguistic expressions, i.e.: very big (VB), big (B), average (A), little (L), very little (VL). The values are assigned to each of them respectively: $5,4,2,2,1[\mathrm{pt}]$. It is also possible to use the intermediate evaluations: VB/B, B/VB, B/A, A/L, L/VL. In the case when the performed repair contributes to the improvement of the evaluation of criterion, the values of numbers are positive, and in the other case they are negative.

For every $j$-th variant of $i$-th repair, the value growth of building's condition $r_{i j}$ is calculated. This is a weighted average of the value growth $p_{i j k}$, for each of six adopted criteria:

$$
r_{i j}=\sum_{k=1}^{q} p_{i j k} \cdot w_{k}, \quad \forall i=1,2, \ldots, n, \quad \forall j=1,2, \ldots, m,
$$

where: $w_{k}$ - weight $k$-th criterion.

\subsection{The selection of repairs in a building and determination of the amount of renovation contribution}

The scope of suggested repairs in a building cannot usually be included in full in the renovation plan, as it exceeds available financial resources which are at administrator's disposal for the renovation purposes. In such a case, the most favorable scope of renovation is sought, among the set of suggested ones $V=\left(v_{11}, v_{12}, \ldots, v_{n m}\right)$.Two concepts of optimization model were developed in order to solve this problem. In the case of the first variant of a model, the solution which can bring the largest increase of condition of a building is sought, expressed using index $S$, at the budget amount $\mathrm{B}$, being the sum of contributions for a renovation fund $s$. The evaluation of solution $S$ is conducted on the basis of the equation (6). The search for the best solution is defined by the objective function (4). The solution is the set of renovation variants $V$ whose cost $C$ cannot exceed the financial resources being at the disposal within budget $B$ of financial resources, which is provided in the equation (5). The mathematical model of the described concept is provided in the following way:

$$
\begin{gathered}
\max z: z=S ; \\
C \leq B ; \\
S=\sum_{k=1}^{q} O_{k} \cdot w_{k}+\sum_{i=1}^{n} \sum_{j=1}^{m} \sum_{h=1}^{t} r_{i j} \cdot x_{h} ; \\
\sum_{h=1}^{t} x_{h}=1, \quad x_{h} \in\{0,1\} \quad h=1,2, \ldots, t ;
\end{gathered}
$$

$x_{h}=\left\{\begin{array}{l}1, \text { when renovation in } j \text {-th variant of } i \text {-th element, } \\ 0, \text { in the opposite case. }\end{array}\right\}$. 
In the second variant of a model, it was assumed that the lowest cost of renovation $C$ is sought to obtain the adopted value of building condition index $Q$. In order to achieve this, the equation of objective function (4) was replaced by the equation (8):

$$
\begin{gathered}
\min z: z=C ; \\
S \geq Q .
\end{gathered}
$$

The solution to the second variant of a model is finding the most favorable scope of renovation for the assumed evaluation values of each criterion $U_{k}$, which is provided in the form of a condition (10):

$$
\begin{gathered}
U_{k} \geq K_{k} ; \\
K_{k}=O_{k}+\sum_{i=1}^{n} \sum_{j=1}^{m} \sum_{h=1}^{t} p_{i j k} \cdot x_{h},
\end{gathered}
$$

where: $S$ - building condition index, $C$ - costs of renovation, $B$ - renovation budget of a building, $h_{k}$ - binary variable, $p_{i j k}$ - growth of $j$-th variant of $i$-th renovation for $k$-th criterion.

The final stage of a model, for the calculated amounts of repair $C$, is determining the amount of renovation contribution $s(l)$, for the $l$-th referential period expressed in years. Its estimation is performed for the estimated costs $C$ of selected renovation variant. The estimation also requires the knowledge of usable area of a building $P$. The calculations are conducted in accordance with the equation (12):

$$
s(l)=\frac{C}{P \cdot l \cdot 12}\left[\frac{\text { PLN }}{\mathrm{m}^{2} \cdot \text { month }}\right] .
$$

\section{Calculation example}

The six-storey multi-dwelling residential building was adopted to the analysis, which was made in prefabri- cated technology whose usable area is $P=4000 \mathrm{~m}^{2}$. The assessment of its condition was carried out on the basis of six criteria: $k_{1}$ - construction safety, $k_{2}$ - energy savings, $k_{3}$ - protection against noise, $k_{4}$ - hygiene conditions, $k_{5}$ - fire safety, $k_{6}$ - building appearance. Each of the criteria is assigned a particular scope of elements (column 2 of Table 1), which is evaluated with the use of linguistic expressions - see section 1.1. The estimation of weighted average of evaluation of every criterion $O_{k}$ in accordance with the equation (1) required the calculation of the weights values $w_{i k}$ adopted to the assessment of the elements. In order to achieve this, the pseudo-fuzzy scale method (Bucoń, Sobotka 2015) was applied. The outcomes of the evaluations and the calculations of analyzed building are presented in Table 1.

On the basis of the performed evaluation of the condition of elements $O_{i k}$ for each of the six criteria, the scope of renovation was proposed which covers seven repair works that can be conducted in many different ways. The total number of all the proposed renovation variants is 19 . Each of them was subjected to the assessment with the use of linguistic expressions described in section 1.2. The estimation of their growth or loss of values, in relation to each of $k$-th criteria, was performed on the basis of the equation (2). The results of calculations are shown in Table 2.

The calculation of the value of building condition index $(1.96 \mathrm{pt})$ and the value of its growth $r_{i j}$ required determining the relevance $w_{k}$ of the assumed criteria. The application of the fuzzy extension of method AHP (Jaśkowski et al. 2010) allowed obtaining the following

\begin{tabular}{|c|c|c|c|c|c|c|c|c|c|c|c|c|c|}
\hline \multirow{3}{*}{$i$} & \multirow{3}{*}{$\begin{array}{l}\text { Element } \\
\text { name }\end{array}$} & \multicolumn{12}{|c|}{ Element evaluation $O_{i k} /$ element weight $w_{i k}$} \\
\hline & & \multicolumn{12}{|c|}{ Number of $k$-th criterion } \\
\hline & & \multicolumn{2}{|c|}{1} & \multicolumn{2}{|c|}{2} & \multicolumn{2}{|c|}{3} & \multicolumn{2}{|c|}{4} & \multicolumn{2}{|c|}{5} & \multicolumn{2}{|c|}{6} \\
\hline 1 & Walls & $\mathrm{B}$ & 0.28 & VB & 0.36 & $\mathrm{~A} / \mathrm{B}$ & 0.41 & VB & 0.25 & $\mathrm{G} / \mathrm{A}$ & 0.24 & VB & 0.25 \\
\hline 2 & Roofs & $\mathrm{A} / \mathrm{B}$ & 0.18 & $\mathrm{~B}$ & 0.18 & A & 0.23 & VB & 0.16 & A & 0.19 & $\mathrm{~B} / \mathrm{VB}$ & 0.09 \\
\hline 3 & Balconies & VB & 0.20 & $\mathrm{~A} / \mathrm{B}$ & 0.04 & $\mathrm{~N}$ & 0 & VB & 0.12 & $\mathrm{~A} / \mathrm{B}$ & 0.07 & B & 0.15 \\
\hline 4 & External woodwork & $\mathrm{N}$ & 0 & VB & 0.21 & B & 0.27 & VB & 0.17 & $\mathrm{~A} / \mathrm{B}$ & 0.19 & B & 0.17 \\
\hline 5 & Basement ceiling & A & 0.12 & VB & 0.13 & B & 0.09 & $\mathrm{~A} / \mathrm{B}$ & 0.08 & A & 0.13 & $\mathrm{~A} / \mathrm{B}$ & 0.06 \\
\hline 6 & Stairway stairs & A & 0.08 & $\mathrm{~N}$ & 0 & $\mathrm{~N}$ & 0 & A & 0.07 & A & 0.11 & B & 0.19 \\
\hline 7 & Basement walls & $\mathrm{A} / \mathrm{B}$ & 0.14 & $\mathrm{~A} / \mathrm{B}$ & 0.08 & $\mathrm{~N}$ & 0 & VB & 0.15 & A & 0.07 & B & 0.09 \\
\hline & Evaluation $O_{k}[\mathrm{pt}]$ & \multicolumn{2}{|c|}{2.16} & \multicolumn{2}{|c|}{1.36} & \multicolumn{2}{|c|}{2.435} & \multicolumn{2}{|c|}{1.26} & \multicolumn{2}{|c|}{2.99} & \multicolumn{2}{|c|}{1.735} \\
\hline
\end{tabular}
values of weights: $w_{1}=0.29, w_{2}=0.24, w_{3}=0.09, w_{4}=$ $0.11, w_{5}=0.14, w_{6}=0.13$. The outcomes of calculations are presented in Table 2.

Table 1. The evaluation of adopted building criteria 
Table 2. The evaluation of growth or loss of values of criteria for the proposed variants of building renovation

\begin{tabular}{|c|c|c|c|c|c|c|c|c|c|c|c|}
\hline \multirow{3}{*}{\multicolumn{2}{|c|}{$\begin{array}{l}\text { Number } \\
\text { of element } \\
\text { renovation } i\end{array}$}} & \multirow{3}{*}{\multicolumn{2}{|c|}{$\begin{array}{l}\text { Description and number } \\
\text { of renovation variant } j\end{array}$}} & \multirow{2}{*}{\multicolumn{6}{|c|}{$\frac{p_{i j k}[\mathrm{pt}]}{k \text { - criterion number }}$}} & \multirow{4}{*}{$\begin{array}{c}r_{i j} \\
{[\mathrm{pt}]}\end{array}$} & \multirow{4}{*}{$\begin{array}{c}C \\
{[\mathrm{PLN}]}\end{array}$} \\
\hline & & & & & & & & & & & \\
\hline & & & & 1 & 2 & 3 & 4 & 5 & 6 & & \\
\hline \multirow{3}{*}{1} & \multirow{3}{*}{$\begin{array}{l}\text { External } \\
\text { walls } \\
\text { (facade) }\end{array}$} & 1 & $\begin{array}{l}\text { Wall renovation, insulation } \\
\text { (styrofoam), thin } \\
\text { coat plaster }\end{array}$ & 0.672 & 1.44 & 0.615 & 0.6 & -0.288 & 0.8 & & \\
\hline & & 2 & $\begin{array}{l}\text { Wall renovation, insulation } \\
\text { (wool), thin coat plaster. }\end{array}$ & 0.672 & 1.44 & 0.923 & 0.9 & 0.36 & 0.8 & 0.877 & 410000 \\
\hline & & 3 & $\begin{array}{l}\text { Wall renovation, insulation } \\
\text { (wool), dry lining }\end{array}$ & 0.672 & 1.44 & 0.923 & 0.9 & 0.36 & 1 & 0.903 & 480000 \\
\hline \multirow{4}{*}{2} & \multirow{4}{*}{ Roof } & 1 & $\begin{array}{l}\text { renovation, cover replacement, } \\
\text { insulation (wool) }\end{array}$ & 0.36 & 0.54 & 0.414 & 0.576 & 0.38 & 0.252 & 0.421 & 123300 \\
\hline & & 2 & $\begin{array}{l}\text { renovation, cover replacement, } \\
\text { insulation (styrofoam) }\end{array}$ & 0.36 & 0.54 & 0.276 & 0.512 & -0.304 & 0.252 & 0.305 & 114500 \\
\hline & & 3 & renovation, cover replacement & 0.36 & 0 & 0 & 0.384 & 0 & 0.252 & 0.179 & 85600 \\
\hline & & 4 & $\begin{array}{l}\text { renovation, cover replacement- } \\
\text { (sprayfoam) }\end{array}$ & 0.36 & 0.216 & 0.184 & 0.384 & -0.304 & 0.189 & 0.197 & 76100 \\
\hline \multirow{3}{*}{3} & \multirow{3}{*}{ Balconies } & 1 & Renovation of board and plaster & 0.64 & 0 & 0 & 0.288 & 0 & 0.27 & 0.252 & 34331 \\
\hline & & 2 & $\begin{array}{l}\text { renovation, thermal insulation, } \\
\text { implementation of board cladding }\end{array}$ & 0.64 & 0.04 & 0 & 0.384 & 0 & 0.315 & 0.278 & 177716 \\
\hline & & 3 & As above, replacement of balustrades & 0.64 & 0.04 & 0 & 0.384 & 0 & 0.36 & 0.284 & 207403 \\
\hline \multirow{3}{*}{4} & \multirow{3}{*}{$\begin{array}{l}\text { External } \\
\text { woodwork }\end{array}$} & 1 & renovation, painting & 0 & 0.168 & 0.162 & 0.136 & 0 & 0.102 & 0.083 & 25000 \\
\hline & & 2 & replacement (woodwork) & 0 & 0.84 & 0.81 & 0.68 & 0 & 0.51 & 0.416 & 170000 \\
\hline & & 3 & replacement (PCV joinery) & 0 & 0.84 & 0.81 & 0.68 & -0.38 & 0.51 & 0.362 & 145000 \\
\hline \multirow{2}{*}{5} & \multirow{2}{*}{$\begin{array}{l}\text { Basement } \\
\text { ceiling }\end{array}$} & 1 & insulation (wool) & 0 & 0.52 & 0.27 & 0.2 & 0.26 & 0.15 & 0.227 & 82680 \\
\hline & & 2 & insulation (styrofoam) & 0 & 0.52 & 0.27 & 0.2 & -0.208 & 0.15 & 0.161 & 93480 \\
\hline \multirow{2}{*}{6} & \multirow{2}{*}{$\begin{array}{l}\text { Internal } \\
\text { stairs }\end{array}$} & 1 & $\begin{array}{l}\text { Renovation of cladding, plaster, } \\
\text { balustrades }\end{array}$ & 0 & 0 & 0 & 0.084 & 0 & 0.285 & 0.046 & 30783 \\
\hline & & 2 & $\begin{array}{l}\text { Replacement of cladding, plaster, } \\
\text { balustrades }\end{array}$ & 0 & 0 & 0 & 0.14 & 0 & 0.57 & 0.090 & 86842 \\
\hline \multirow[b]{2}{*}{7} & \multirow[b]{2}{*}{$\begin{array}{l}\text { Basement } \\
\text { walls }\end{array}$} & 1 & $\begin{array}{l}\text { Replacement of damp-proof } \\
\text { insulation }\end{array}$ & 0.28 & 0 & 0 & 0.48 & 0 & 0.216 & 0.162 & 76430 \\
\hline & & 2 & $\begin{array}{l}\text { Replacement of damp-proof } \\
\text { insulation, implementation } \\
\text { of thermal insulation }\end{array}$ & 0.35 & 0.12 & 0 & 0.6 & 0 & 0.27 & 0.231 & 94510 \\
\hline
\end{tabular}

Subsequently, the calculations were conducted in accordance with section 1.3. The first variant of the optimization model was used to select the most favorable scope of renovation, which will ensure achieving the growth of building condition index $S$ while limiting the amount of budget $B=(100,200, \ldots, 1300)$ thousand PLN). The values of evaluations, achieved by particular criteria, were also calculated. The outcomes are shown in Table 3.

The next task, to the solution of which the second variant of a model was applied, concerns the search for the most favorable scope of renovation that at the lowest cost of performance enables the achievement of assumed values of building condition $Q$. The calculations were conducted for the assumed values $Q=\{2.5,3.0, \ldots, 4.5\} \mathrm{pt}$. The outcomes are shown in Table 4.

While applying the second variant of a model, more detailed calculations were also performed. Their aim was to find the most favorable renovation variant of a building to obtain the assumed values of evaluations of each of $k$-th criteria, adopting the lowest cost of renovation performance $C$ as the optimization criterion. 
R. Bucoń, M. Tomczak. Supporting building administrator's decisions in determining maintenance costs ...

Table 3. The achieved values of building condition index $S$ for the assumed budget amounts $B$.

\begin{tabular}{|c|c|c|c|c|c|c|c|c|c|}
\hline \multirow{3}{*}{$\begin{array}{c}B \\
{[\mathrm{PLN}]}\end{array}$} & \multirow{3}{*}{$\begin{array}{c}C \\
{[\mathrm{PLN}]}\end{array}$} & \multirow{3}{*}{$\begin{array}{c}S \\
{[\mathrm{pt}]}\end{array}$} & \multicolumn{6}{|c|}{$K_{k}[\mathrm{pt}]$} & \multirow{3}{*}{$\begin{array}{c}\text { Renovation variant } \\
v_{i j}\end{array}$} \\
\hline & & & \multicolumn{6}{|c|}{$k$-th criterion number } & \\
\hline & & & 1 & 2 & 3 & 4 & 5 & 6 & \\
\hline 100000 & 90114 & 2.34 & 2.8 & 1.53 & 2.6 & 1.77 & 2.99 & 2.4 & $3 / 1,4 / 1,6 / 1$ \\
\hline 200000 & 182631 & 2.71 & 3.16 & 2.07 & 3.02 & 2.26 & 3.37 & 2.36 & $2 / 1,3 / 1,4 / 1$ \\
\hline 300000 & 296094 & 2.99 & 3.16 & 2.59 & 3.29 & 2.54 & 3.63 & 2.80 & $2 / 1,3 / 1,4 / 1,5 / 1,6 / 1$ \\
\hline 400000 & 397141 & 3.22 & 3.51 & 2.86 & 3.66 & 3.40 & 2.99 & 3.04 & $2 / 1,3 / 1,4 / 3,7 / 2$ \\
\hline 500000 & 479821 & 3.45 & 3.51 & 3.38 & 3.93 & 3.60 & 3.25 & 3.19 & $2 / 1,3 / 1,4 / 3,5 / 1,7 / 2$ \\
\hline 600000 & 591663 & 3.59 & 3.51 & 3.38 & 3.93 & 3.74 & 3.63 & 3.76 & $2 / 1,3 / 1,4 / 2,5 / 1,6 / 2,7 / 2$ \\
\hline 700000 & 687141 & 3.82 & 4.18 & 3.63 & 3.94 & 3.76 & 3.73 & 3.43 & $1 / 2,2 / 1,3 / 1,4 / 1,7 / 2$ \\
\hline 800000 & 795311 & 4.10 & 3.83 & 4.7 & 4.86 & 3.9 & 3.61 & 3.72 & $1 / 2,2 / 1,3 / 1,4 / 3,5 / 1$ \\
\hline 900000 & 889821 & 4.33 & 4.18 & 4.82 & 4.86 & 4.5 & 3.61 & 3.99 & $1 / 2,2 / 1,3 / 1,4 / 3,5 / 1,7 / 2$ \\
\hline 1000000 & 945604 & 4.43 & 4.18 & 4.82 & 4.86 & 4.59 & 3.99 & 4.28 & $1 / 2,2 / 1,3 / 1,4 / 2,5 / 1,6 / 1,7 / 2$ \\
\hline 1100000 & 1071663 & 4.50 & 4.18 & 4.82 & 4.86 & 4.64 & 3.99 & 4.76 & $1 / 3,2 / 1,3 / 1,4 / 2,5 / 1,6 / 2,7 / 2$ \\
\hline 1300000 & 1244735 & 4.53 & 4.18 & 4.86 & 4.86 & 4.74 & 3.99 & 4.85 & $1 / 3,2 / 1,3 / 3,4 / 2,5 / 1,6 / 2,7 / 2$ \\
\hline
\end{tabular}

Table 4. The cost of renovation $C$ for the assumed values of building condition $S \geq Q$

\begin{tabular}{|c|c|c|c|c|c|c|c|c|c|}
\hline \multirow{3}{*}{$\begin{array}{c}Q \\
{[\mathrm{pt}]}\end{array}$} & \multirow{3}{*}{$\begin{array}{c}S \\
{[\mathrm{pt}]}\end{array}$} & \multirow{3}{*}{$\begin{array}{c}C \\
{[\mathrm{PLN}]}\end{array}$} & \multicolumn{6}{|c|}{$K_{k}[\mathrm{pt}]$} & \multirow{3}{*}{$\begin{array}{c}\text { Renovation variant } \\
v_{i j}\end{array}$} \\
\hline & & & \multicolumn{6}{|c|}{$k$ - th criterion number } & \\
\hline & & & 1 & 2 & 3 & 4 & 5 & 6 & \\
\hline 2.5 & 2.52 & 142011 & 2.8 & 2.05 & 2.87 & 1.88 & 3.25 & 2.26 & $3 / 1,4 / 1,5 / 1$ \\
\hline 3.0 & 3.02 & 316741 & 3.44 & 2.42 & 3.12 & 2.80 & 3.63 & 2.63 & $2 / 1,3 / 1,5 / 1,7 / 1$ \\
\hline 3.5 & 3.50 & 504821 & 3.51 & 3.38 & 3.93 & 3.60 & 3.63 & 3.19 & $2 / 1,3 / 1,4 / 2,5 / 1,7 / 2$ \\
\hline 4.0 & 4.05 & 769821 & 4,18 & 4,15 & 4,21 & 3,96 & 3.99 & 3,58 & $1 / 2,2 / 1,3 / 1,4 / 1,5 / 1,7 / 2$ \\
\hline 4.5 & 4.50 & 1071663 & 4.18 & 4.82 & 4.86 & 4.64 & 3.99 & 4.76 & $1 / 3,2 / 1,3 / 1,4 / 2,5 / 1,6 / 2,7 / 2$ \\
\hline
\end{tabular}

Table 5. The cost of renovation $C$ for the improvement of criteria value

\begin{tabular}{|c|c|c|c|c|c|c|c|c|}
\hline \multirow{2}{*}{$\frac{U_{k}[\mathrm{pt}]}{k \text {-th criterion }}$} & \multicolumn{6}{|c|}{$K_{k}[\mathrm{pt}]$} & \multirow{2}{*}{$\begin{array}{c}\text { Renovation variant } \\
v_{i j}\end{array}$} & \multirow{2}{*}{$\begin{array}{c}C \\
{[\mathrm{PLN}]}\end{array}$} \\
\hline & 1 & 2 & 3 & 4 & 5 & 6 & & \\
\hline 1 & 4.11 & 3.02 & 3.55 & 3.31 & 3.05 & 3.22 & $1 / 2,2 / 4,3 / 1,7 / 1$ & 596861 \\
\hline 1,2 & 4.11 & 4.03 & 3.90 & 3.54 & 3.34 & 3.53 & $1 / 1,2 / 1,3 / 1,4 / 1,5 / 1,7 / 1$ & 721741 \\
\hline $1,2,3$ & 4.11 & 4.03 & 4.07 & 3.78 & 3.31 & 3.53 & $1 / 2,2 / 2,3 / 1,4 / 1,5 / 1,7 / 1$ & 742941 \\
\hline $1,2,3,4$ & 4.11 & 4.18 & 4.59 & 4.18 & 3.35 & 3.79 & $1 / 2,2 / 1,3 / 1,4 / 3,7 / 1$ & 789061 \\
\hline $1,2,3,4,5$ & 4.18 & 4.15 & 4.21 & 4.04 & 3.99 & 3.87 & $1 / 2,2 / 1,3 / 1,4 / 1,5 / 1,6 / 1,7 / 2$ & 800604 \\
\hline $1,2,3,4,5,6$ & 4.18 & 4.15 & 4.21 & 4.10 & 3,99 & 4.15 & $1 / 2,2 / 1,3 / 1,4 / 1,5 / 1,6 / 2,7 / 2$ & 856663 \\
\hline
\end{tabular}

The calculation of the amount of contribution for the so-called renovation fund $s(l)$ was performed on the basis of the obtained values of the building condition index $S$ from Table 4 (for the six highest values). The calculations were conducted on the basis of the Equation (13). The results $s(l)$ for the particular values of exploitation condition are presented in Table 6. The calculations were performed for nine reference periods $l$, from 4 to 12 years.
The results listed in Table 6 enable the selection of the most appropriate variant to finance the repairs. It defines the monthly amount of contribution of renovation fund, paid by the residents, in the period of $n$ years, to achieve by the building the assumed value of the building condition index. 
Table 6. Variants of the amount of renovation contribution $s(l)$ in the years, for the value of the building condition index $S$

\begin{tabular}{|c|c|c|c|c|c|c|c|c|c|c|}
\hline \multirow{3}{*}{$\begin{array}{c}S \\
{[\mathrm{pt}]}\end{array}$} & \multirow{3}{*}{$\begin{array}{c}C \\
{[\mathrm{PLN}]}\end{array}$} & \multicolumn{9}{|c|}{ The amount of renovation contribution $s(l)\left[\mathrm{PLN} / \mathrm{m}^{2}\right.$ month] } \\
\hline & & \multicolumn{9}{|c|}{$l$ [years] } \\
\hline & & 4 & 5 & 6 & 7 & 8 & 9 & 10 & 11 & 12 \\
\hline 3.82 & 687141 & 3,58 & 2,86 & 2,39 & 2,05 & 1,79 & 1,59 & 1,43 & 1,3 & 1,19 \\
\hline 4.10 & 795311 & 4,14 & 3,31 & 2,76 & 2,37 & 2,07 & 1,84 & 1,66 & 1,51 & 1,38 \\
\hline 4.33 & 889821 & 4,63 & 3,71 & 3,09 & 2,65 & 2,32 & 2,06 & 1,85 & 1,69 & 1,54 \\
\hline 4.43 & 945604 & 4,93 & 3,94 & 3,28 & 2,81 & 2,46 & 2,19 & 1,97 & 1,79 & 1,64 \\
\hline 4.50 & 1071663 & 5,58 & 4,47 & 3,72 & 3,19 & 2,79 & 2,48 & 2,23 & 2,03 & 1,86 \\
\hline 4.53 & 1244735 & 6,48 & 5,19 & 4,32 & 3,7 & 3,24 & 2,88 & 2,59 & 2,36 & 2,16 \\
\hline
\end{tabular}

\section{Conclusions}

The method presented in the article is the multi-stage approach to determine the costs of renovation of multi-dwelling residential buildings. Its development required the application of appropriate calculation tools to solve the particular problems at their particular stages. One of them was the application of the linguistic evaluations to assess the assumed criteria of a building and the impact of proposed repairs on the improvement or the loss of their values. At evaluation of criteria of a building, as well as the whole building, the pseudo-fuzzy scale methods and the fuzzy extension of method AHP were applied. The determination of the most favorable scope of repairs in a building was the target stage of the suggested approach. The authors developed two different approaches of optimum selection of renovation variant based on linear programming. The use of each of proposed approaches enables to determine alternative renovation variants to achieve assumed criteria values or building evaluation and the cost of their realization. It also enables to specify the contribution for the so-called renovation fund which would be incurred by the residents in the assumed period.

The developed model is matched to the needs of strategic planning of housing estate management. It can also be applied as a tool supporting the work of a property manager in terms of multi-criteria evaluation of condition of a building and the selection of renovation variant with regard to financial limitations.

\section{References}

Alchimoviene, J.; Raslanas, S. 2011. Sustainable renovation and evaluation of Block of Multi-apartment house, in The 8th International Conference, 19-20 May 2011, Vilnius, Lithuania, 835-841.
Bucoń, R.; A. Sobotka, A. 2015. Decision making model for choosing residential building repair variants, Journal of Civil Engineering and Management 21(7): 893-901. http://dx.doi.org/10.3846/13923730.2014.895411

Caccavelli, D.; Gugerli, H. 2002. TOBUS - a European diagnosis and decision-making tool for Office building upgrading, Energy and Buildings 34(2): 113-119. http://dx.doi.org/10.1016/S0378-7788(01)00100-1

Christen, M.; Schroeder, J.; Wallbaum, H. 2014. Evaluation of strategic building maintenance and refurbishment budgeting method Schroeder, International Journal of Strategic Property Management 18(4): 393-406.

http://dx.doi.org/10.3846/1648715X.2014.971917

Dascalaki, E.; Balaras, C. A. 2004. XENIOS - a methodology for assessing refurbishment scenarios and the potential of applications of RES and RUE in hotels, Energy and Buildings 36(11): 1091-1105. http://dx.doi.org/10.1016/j.enbuild.2004.03.007

Ho; D. C. W.; Chau, K. W.; Cheung, A. K. C.; Yau, Y.; Wong, S. K.; Leung, H. F.; Lau, S. S. Y.; Wong, W. S. 2008. A survey of the health and safety conditions of apartment buildings in Hong Kong, Building and Environment 43(5): 764-775. http://dx.doi.org/10.1016/j.buildenv.2007.01.035

Ho, D. C. W.; Yau, Y.; Poon, S. W.; Liusman, E. 2012. Achieving sustainable urban renewal in Hong Kong: a strategy for dilapidation assessment of high rises, Journal of Urban Planning and Development 138(2): 153-165. http://dx.doi.org/10.1061/(ASCE)UP.1943-5444.0000104

Jaśkowski, P.; Biruk, S.; Bucoń; R. 2010. Assessing contractor selection criteria weights with fuzzy AHP method application in group decision environment, Automation in Construction 19(2): $120-126$.

http://dx.doi.org/10.1016/j.autcon.2009.12.014

Juan, Y. K.; Kim, J. H.; Roper, K.; Lacouture, D. C. 2009. GAbased decision support system for housing condition assessment and refurbishment strategies, Automation in Construction 18(4): 394-401. http://dx.doi.org/10.1016/j.autcon.2008.10.006

Kaklauskas, A.; Zavadskas, E. K.; Raslanas, S. 2005. Multivariant design and multiple criteria analysis of building refurbishments, Energy and Buildings 37(4): 361-372. http://dx.doi.org/10.1016/j.enbuild.2004.07.005

Kasprowicz, T. 2005. Modelling of complex small buildings operation and maintenance, in The 9th International Confer- 
ence on "Inspection, Appraisal - Repairs and Maintenance of Structures, 19-21 October 2005, Fuzhou, China, 297-304.

Kolokotsa, D.; Diakaki, C.; Grigoroudis, E.; Stavrakakis, G.; Kalaitzakis, K. 2009. Decision support methodologies on the energy efficiency and energy management in buildings, $A d$ vances in Building Energy Research 9(3): 121-146. http://dx.doi.org/10.3763/aber.2009.0305

Lin, Y. Y.; Pan, N.-H. 2014. Multi period performance assessment model for the site property management, International Journal of Strategic Property Management 18(4): 332-343. http://dx.doi.org/10.3846/1648715X.2014.970596

Mickaityte, A.; Zavadskas, E. K.; Kaklauskas, A.; Tupenaite, L. 2008. The concept model of sustainable buildings refurbishment, International Journal of Strategic Property Management 12(1): 53-68.

http://dx.doi.org/10.3846/1648-715X.2008.12.53-68

Perng, Y. H.; Juan, Y. H.; Hsu, H. S. 2007. Genetic algorithmbased decision support for the restoration budget allocation of historical buildings, Building and Environment 42(2): 770-778. http://dx.doi.org/10.1016/j.buildenv.2005.09.009

Raslanas, S.; Alchimoviene, J.; Banaitiene, N. 2011. Residential areas with apartment houses: analysis of the condition of buildings, planning issues, retrofit strategies and scenarios, International Journal of Strategic Property Management 15(2): 152-172. http://dx.doi.org/10.3846/1648715X.2011.586531

Reed, R.; Wilkinson, S.; Bilos, A.; Schulte, K. W. 2011. A comparison of international sustainable building tools - an up- date, in The 17 th Annual Pacific Rim Real Estate Society Conference, 16-19 January 2011, Gold Coast, 1-16.

Roderick, Y.; McEwan, D.; Wheatley, C.; Alonso, C. 2009. Comparison of energy performance assessment between LEED, BREEAM and GREEN STAR, in The 11th International Conference (IBPSA-2009), 27-30 July 2009, Glasgow, Scotland, $1167-1176$.

Rosenfiels, Y.; Shohet, I. M. 1999. Decision support model for semi - automated selection of renovation alternatives, $A u$ tomation in Construction 8(4): 503-510. http://dx.doi.org/10.1016/S0926-5805(98)00097-1

The Real Estate Management Act from August 21, 1997, 112 p. (in Polish).

Yau, Y. 2008. Building conditions in Yau Tsim Mong, Hong Kong: appraisal, exploration and estimation, Journal of Building Appraisal 3(4): 319-329. http://dx.doi.org/10.1057/jba.2008.8

Yau, Y.; Ho, D. C. W.; Chau, K. W. 2008. Determinants of the safety performance of private multi-storey residential buildings in Hong Kong, Social Indicators Research 89(3): 501521. http://dx.doi.org/10.1007/s11205-008-9246-3

Zavadskas, E. K.; Kaklauskas, A.; Raslanas, S. 2004. Evaluation of investments into housing renovation, International Journal of Strategic Property Management 8(3): 177-190.

Zavadskas, E. K.; Kaklauskas, A.; Turskis, Z. 1997. Multicriteria decision-making system for building retrofit, Journal of Civil Engineering and Management 3(4): 62-68.

Robert BUCOŃ is PhD at Lublin University of Technology, Faculty of Civil Engineering and Architecture, Department of Construction Project Engineering in Poland. Academic degree: PhD in civil engineering from Lublin University of Technology (2013). Author of about 40 scientific articles. Research interests: construction technology and organisation, project management, properties management, management and sustainable development in construction, simulation modelling and multiple criteria decision making, expert systems, mathematical programming, operation research.

Michał TOMCZAK is MSc at Lublin University of Technology, Faculty of Civil Engineering and Architecture, Department of Construction Project Engineering in Poland. Academic degree: MSc in civil engineering from Lublin University of Technology (2012). Author of over 10 scientific articles. Research interests: supply chain management, construction technology and organisation, project management, small and medium construction entertainment, ready-mix concrete distribution, vehicle routing problem and mathematical programming, operation research. 